\title{
The effects of obesity-associated insulin resistance on mRNA expression of peroxisome proliferator-activated receptor- $\gamma$ target genes, in dogs
}

\author{
Constance Gayet ${ }^{1}$, Veronique Leray ${ }^{1}$, Masayuki Saito ${ }^{2}$, Brigitte Siliart ${ }^{1}$ and Patrick Nguyen ${ }^{1 *}$ \\ ${ }^{1}$ Nutrition and Endocrinology Unit, National Veterinary School, B.P. 40706, F 44307 Nantes Cedex 3, France \\ ${ }^{2}$ Laboratory of Biochemistry, Department of Biomedical Sciences, Graduate School of Veterinary Medicine, \\ Hokkaido University, Sapporo, Japan
}

(Received 27 July 2006 - Revised 26 January 2007 - Accepted 1 February 2007)

\begin{abstract}
Visceral adipose tissue and skeletal muscle have central roles in determining whole-body insulin sensitivity. The peroxisome proliferator-activated receptor- $\gamma(\operatorname{PPAR} \gamma)$ is a potential mediator of insulin sensitivity. It can directly modulate the expression of genes that are involved in glucose and lipid metabolism, including GLUT4, lipoprotein lipase (LPL) and adipocytokines (leptin and adiponectin). In this study, we aimed to determine the effects of obesity-associated insulin resistance on mRNA expression of PPAR $\gamma$ and its target genes. Dogs were studied when they were lean and at the end of an overfeeding period when they had reached a steady obese state. The use of a sensitive, real-time PCR assay allowed a relative quantification of mRNA expression for PPAR $\gamma$, LPL, GLUT4, leptin and adiponectin, in adipose tissue and skeletal muscle. In visceral adipose tissue and/or skeletal muscle, mRNA expression of PPAR $\gamma$, LPL and GLUT4 were at least 2-fold less in obese and insulin-resistant dogs compared with the same animals when they were lean and insulin-sensitive. The mRNA expression and plasma concentration of leptin was increased, whereas the plasma level and mRNA expression of adiponectin was decreased, by obesity. In adipose tissue, PPAR $\gamma$ expression was correlated with leptin and adiponectin. These findings, in an original model of obesity induced by a prolonged period of overfeeding, showed that insulin resistance is associated with a decrease in PPAR $\gamma$ mRNA expression that could dysregulate expression of several genes involved in glucose and lipid metabolism.
\end{abstract}

Insulin resistance: Obesity: Peroxisome proliferator-activated receptor: mRNA

Obesity-induced insulin resistance is associated with metabolic disorders and profound changes in glucose and lipid homeostasis. Insulin resistance is characterised by a decrease in the uptake of glucose, especially by insulin target tissues (including adipose tissue and skeletal muscle), and is accompanied by abnormal production of adipocytokines.

Peroxisome proliferator-activated receptor (PPAR $\gamma$ ) may contribute to increased insulin sensitivity in muscle and adipose tissue by some as yet undefined molecular pathways. PPAR $\gamma$ promotes adipocyte differentiation, resulting in an increased number of small adipocytes more sensitive to insu$\operatorname{lin}^{1}$, whilst in mature adipocytes, PPAR $\gamma$ plays a key role in lipid and glucose homeostasis through co-ordinate effects on gene transcription.

Most of its target genes encode proteins involved in the trapping, release and storage of fatty acids, such as $\mathrm{LPL}^{2}$, leptin $^{3}, \mathrm{TNF}^{4}$ and adiponectin ${ }^{5,6}$, and in proteins directly involved in glucose uptake such as the insulin-dependent glucose transporter GLUT4 ${ }^{7,8}$.

In both rodents and man the majority of PPAR $\gamma$ is expressed in adipose tissue, and it is expressed at much lower levels in skeletal muscle. Whilst the role of PPAR $\gamma$ in insulin resistance and obesity is evident, the effects of these diseases on its own expression are still unclear. In obese and type 2 diabetic subjects, it has been reported that PPAR $\gamma$ gene expression was increased in skeletal muscle ${ }^{9}$, and not altered in adipose tissue ${ }^{10}$. In contrast, it has been demonstrated that expression of PPAR $y$ mRNA was increased in the adipose tissue of obese subjects, but not changed in the muscle of lean, obese or diabetic subjects ${ }^{11}$. Reports that people with dominant negative mutations in the PPAR $\gamma$ gene suffer from severe insulin resistance suggest that PPAR $\gamma$ expression may be decreased in the insulin-resistant state $^{12}$.

For many years, dogs have been used as a model of the human metabolic syndrome ${ }^{13}$. Following sequencing of the dog genome, the high degree of homology between canine and human genes ${ }^{14}$ provides further support for the validity of this model.

In the present study, we determined the effects of obesity and insulin resistance on the expression of PPAR $\gamma$ and some of its target genes (including LPL, GLUT4, adiponectin, leptin, $\mathrm{TNF} \alpha$ ) in the skeletal muscle and/or visceral adipose tissue of dogs following prolonged overfeeding. Plasma concentrations of insulin, TAG, leptin and adiponectin were also determined.

Abbreviations: BW, body weight; LPL, lipoprotein lipase; PPAR $\gamma$, peroxisome proliferator-activated receptor- $\gamma$.

* Corresponding author: Prof. Patrick Nguyen, fax +33 240687 746, email pnguyen@vet-nantes.fr 


\section{Materials and methods}

\section{Animals}

Thirteen healthy, adult, neutered, female dogs (beagles) participated in the study. Among the thirteen dogs, seven (initial body weight (BW) 11.1 (SEM 0.8) kg; age 21.6 (SEM 1.2) months) were used for the entire study, forming their own control and being assessed both before and after the overfeeding period. The other six dogs (initial BW 8.5 (SEM 0.4) kg; age 37.6 (SEM 2.0) months) were used as a control group for the study of PPAR $\gamma$ mRNA expression in subcutaneous adipose tissue. The dogs were housed at the National Veterinary School (Nantes, France) according to the animal welfare regulations of the French Ministry of Agriculture and Fisheries. The experimental protocols adhered to European Union guidelines and were approved by the Animal Use and Care Advisory Committee of Nantes (France).

\section{Experimental design}

In order to promote obesity and insulin resistance, seven dogs were fed a high-fat diet (Table 1), with a food allowance of 1.5 times the National Research Council recommendation for canine maintenance, i.e. $816 \mathrm{~kJ}$ metabolizable energy $/ \mathrm{kg}$ $\mathrm{BW}^{0.75}$, based on initial $\mathrm{BW}$. The remaining six dogs were fed a control diet at the National Research Council recommendation for maintenance (544 kJ metabolizable energy $/ \mathrm{kg}$ $\mathrm{BW}^{0.75}$; Table 1). Individual food intakes were recorded daily and BW were recorded weekly. The dogs were considered to be obese when they had gained more than $25 \%$ of their initial BW. An obese steady state was considered to have been achieved when BW had not changed for at least 8 weeks. Dogs were studied before weight gain and when they had reached the obese steady state.

Insulin sensitivity was assessed using the euglycaemic hyper-insulinaemic glucose clamp technique (as previously described $^{15}$ ), prior to weight gain and after achieving an obese steady state. Blood samples were collected monthly following an overnight fast. For TAG, leptin and adiponectin analyses, blood samples $(10 \mathrm{ml})$ were taken from the jugular vein into EDTA tubes $(23.5 \mu \mathrm{mol} /$ tube $)$. The blood was immediately centrifuged at $4300 \mathrm{~g}$ for $10 \mathrm{~min}$ and plasma aliquots were frozen at $-20^{\circ} \mathrm{C}$ until analysis.

Table 1. Nutrient profile, in the commercially available high-fat diet used to promote obesity $(n 7)$ and the control used to maintain body weight $(n 6)$

\begin{tabular}{lcc}
\hline Nutrients & High-fat diet† & Control diet \\
\hline Moisture $(\mathrm{g} / 100 \mathrm{~g})$ & $5 \cdot 7$ & $6 \cdot 7$ \\
Protein $(\mathrm{g} / 100 \mathrm{~g})$ & 24.8 & 18.3 \\
Fat $(\mathrm{g} / 100 \mathrm{~g})$ & 20.8 & 15.0 \\
Ash $(\mathrm{g} / 100 \mathrm{~g})$ & $6 \cdot 1$ & 5.8 \\
Starch $(\mathrm{g} / 100 \mathrm{~g})$ & $36 \cdot 1$ & 31.4 \\
Total dietary fibre $(\mathrm{g} / 100 \mathrm{~g})$ & 2.8 & 8.5 \\
Metabolizable energy $(\mathrm{kJ} / \mathrm{g})$ & 18.0 & 14.0 \\
\hline
\end{tabular}

†High-fat diet contained rice, poultry meal, animal fat, beet pulp, poultry protein isolate, minerals, pea fibre, Torula yeast, soya oil, fish oil, minerals, trace elements, vitamins.

$\ddagger$ Control diet contained barley, poultry meal, pea fibre, animal fat, beet pulp, poultry protein isolate, Torula yeast, soya oil, minerals, fish oil, minerals, trace elements, lysine, vitamins, methionine.
Biopsies of visceral and subcutaneous adipose tissue and skeletal muscle were obtained under anaesthesia following an overnight fast, 1 week after the euglycaemic glucose clamp. Skeletal muscle biopsies were removed from a rear thigh and the adipose tissue samples were mesenteric. Approximately $100 \mathrm{mg}$ of each tissue were taken, and cleaned in saline before $1 \mathrm{ml}$ TRIzol reagent (Gibco BRL, Grand Island, NY, USA) was added and the tissue was immediately frozen in liquid nitrogen.

\section{Chemical analysis}

Rapid determination of blood glucose during clamping was achieved using the glucose oxidase method (Glucotrend ${ }^{\circledR}$ Plus; Roche Diagnostics, Mannheim, Germany). Plasma immunoreactive insulin concentrations (RIA Insik-5; DiaSorin, Saluggia, Italy) and plasma immunoreactive adiponectin concentrations (RIA kit; LINCO Research Inc., St Charles, MO, USA) were measured using commercial RIA kits. Plasma TAG concentrations were analysed using enzymatic methods (TG C Wako; Oxoid, Dardilly, France) whilst plasma leptin was quantitated by ELISA $^{16}$.

\section{RNA extraction and analysis}

Total RNA was extracted from adipose tissue and muscle using TRIzol reagent according to the manufacturer's instructions (Gibco BRL). After extraction, RNA samples were treated with ribonuclease-free deoxyribonuclease (Promega Corp., Madison, WI, USA). RNA pellets were dissolved in water. Total RNA concentration was quantified by spectrophotometric absorbance measurement at $260 \mathrm{~nm}$. The 260 -to- $280 \mathrm{~nm}$ absorption ratio of all preparations was between 1.8 and 2.0. RNA integrity was assessed by gel electrophoresis using agarose-ethidium bromide gel.

\section{Reverse transcription and real-time PCR analysis}

Reverse transcription was carried out in a reaction volume of $20 \mu \mathrm{l}$ containing $1 \mu \mathrm{g}$ total RNA, $0.5 \mu \mathrm{g} / \mu \mathrm{l} \mathrm{pdN6}$ primer (Pharmacia, Saclay, Orsay Cedex, France) and Superscript II Moloney leukaemia virus RT (according to the manufacturer's instructions; Life Technologies, Cergy-Pontoise, France).

Quantitative real-time PCR was conducted with a Rotorgene 2000 (Ozyme, Saint-Quentin-en-Yvelines, France) in a $20 \mu \mathrm{l}$ mixture containing 1x SYBR Green (Roche Diagnostic, Meylan, France), $0.25 \mathrm{~mm}$-dNTP, $0.5 \mathrm{~mm}$ of each primer, $2 \mathrm{U}$ Taq Titanium DNA polymerase (Ozyme) and $2 \mu \mathrm{l}$ cDNA mixture of each sample.

The sense/antisense primers (Genosys, Pampisford, UK) were designed using GeneJockey Software (Biosoft, Ferguson, MO, USA). The specificity of PCR primers and the annealing temperature were tested under normal PCR conditions with a temperature gradient $\left(55-70^{\circ} \mathrm{C}\right)$ as annealing (Table 2).

The real-time PCR conditions were $95^{\circ} \mathrm{C}$ for $300 \mathrm{~s}$ (to activate the hot-start enzyme), followed by: (1) thirty-five cycles of $95^{\circ} \mathrm{C}$ for $5 \mathrm{~s}, 63^{\circ} \mathrm{C}$ for $10 \mathrm{~s}, 72^{\circ} \mathrm{C}$ for $10 \mathrm{~s}$ and $83^{\circ} \mathrm{C}$ for $15 \mathrm{~s}$ for PPAR $\gamma$; (2) forty cycles of $95^{\circ} \mathrm{C}$ for $5 \mathrm{~s}, 62^{\circ} \mathrm{C}$ for $15 \mathrm{~s}$, $72^{\circ} \mathrm{C}$ for $15 \mathrm{~s}$ and $86^{\circ} \mathrm{C}$ for $15 \mathrm{~s}$ for the LPL; (3) forty cycles of $95^{\circ} \mathrm{C}$ for $5 \mathrm{~s}, 65^{\circ} \mathrm{C}$ for $10 \mathrm{~s}, 72^{\circ} \mathrm{C}$ for $10 \mathrm{~s}$ and $87^{\circ} \mathrm{C}$ for $15 \mathrm{~s}$ for leptin; (4) forty-five cycles of $95^{\circ} \mathrm{C}$ for $5 \mathrm{~s}, 70^{\circ} \mathrm{C}$ for 
Table 2. Sense/antisense primers used for proliferator-activated receptor- $\gamma$ (PPAR $\gamma$ ), lipoprotein lipase (LPL), GLUT4, leptin, adiponectin, $\mathrm{TNF} \alpha$ and GAPDH relative quantification, and annealing temperatures determined for each PCR primer

\begin{tabular}{|c|c|c|}
\hline Gene & Sense/antisense primers & $\begin{array}{c}\text { Annealing } \\
\text { temperature } \\
\left({ }^{\circ} \mathrm{C}\right)\end{array}$ \\
\hline GAPDH & $\begin{array}{l}\text { 5'-ACAGTCAAGGCTGAGAACGG-3' } \\
\text { 5'-CCACAACATACTCAGCACCAGC-3' }\end{array}$ & 69 \\
\hline LPL & $\begin{array}{l}\text { 5'-GAAGAAAATCCAAGTAAGGC-3' } \\
5^{\prime} \text {-ACATTTTGCTCGGTCTTTTGGC-3' }\end{array}$ & 62 \\
\hline PPAR $\gamma$ & $\begin{array}{l}\text { 5'-CATTTACACGATGCTGGCGTCC- } 3^{\prime} \\
5^{\prime} \text {-CTCCACTGAGAATAATGACGGC-3' }\end{array}$ & 63 \\
\hline Adiponectin & $\begin{array}{l}\text { 5'-CCAGGTCTTGTTGGTCCTAAGG-3' } \\
5^{\prime} \text {-ACACTGAATGCCGAACGG-3' }\end{array}$ & 69 \\
\hline GLUT4 & $\begin{array}{l}\text { 5'-GACAAGCAACTTCATCATTGGC-3' } \\
\text { 5'-AGGAAGGTGAAGATGAAGAAGG-3' }\end{array}$ & 70 \\
\hline Leptin & $\begin{array}{l}\text { 5'-AATGCGTTGTGGACCTCTGTGC-3' } \\
\text { 5'-AATGCGTTGTGGACCTCTGTGC-3' }\end{array}$ & 65 \\
\hline $\mathrm{TNF} \alpha$ & $\begin{array}{l}\text { 5'-AACCCCAAGTGACAAGCCAGTA-3' } \\
5^{\prime} \text {-TCTGGTAGGAGACGGCGAAG-3' }\end{array}$ & 70 \\
\hline
\end{tabular}

$15 \mathrm{~s}, 72^{\circ} \mathrm{C}$ for $15 \mathrm{~s}$ and $85^{\circ} \mathrm{C}$ for $15 \mathrm{~s}$ for GLUT4; (5) forty cycles of $95^{\circ} \mathrm{C}$ for $5 \mathrm{~s}, 69^{\circ} \mathrm{C}$ for $15 \mathrm{~s}, 72^{\circ} \mathrm{C}$ for $15 \mathrm{~s}$ and $86^{\circ} \mathrm{C}$ for $15 \mathrm{~s}$ for adiponectin; (6) forty cycles of $95^{\circ} \mathrm{C}$ for $5 \mathrm{~s}$, $70^{\circ} \mathrm{C}$ for $15 \mathrm{~s}, 72^{\circ} \mathrm{C}$ for $15 \mathrm{~s}$ and $81^{\circ} \mathrm{C}$ for $15 \mathrm{~s}$ for $\mathrm{TNF} \alpha$; or (7) thirty cycles of $95^{\circ} \mathrm{C}$ for $5 \mathrm{~s}, 69^{\circ} \mathrm{C}$ for $15 \mathrm{~s}, 72^{\circ} \mathrm{C}$ for $15 \mathrm{~s}$ and $86^{\circ} \mathrm{C}$ for $15 \mathrm{~s}$ for the GAPDH.

The fluorescence cycle threshold $(C t)$ obtained was used to quantitate the relative amount of gene expression. Relative transcript levels were calculated as $x=2^{-\Delta \Delta C t}$, where $x$-fold is the difference in the amount of starting cDNA between two samples, $\Delta \Delta C t=\left(C t_{\text {target }}-C t_{\text {GAPDH }}\right)_{\text {Time IR }}-\left(C t_{\text {target }}-C t_{\text {GAPDH }}\right)_{\text {Time } 0}$. GAPDH, as a housekeeping gene (the level of mRNA GAPDH is not significantly different between the two groups) was used as a reference for initial RNA loading. Time IR was designated as the time-point when the dogs were obese and insulin-resistant. Time 0 represents the one-fold expression of the target gene normalized to GAPDH when the same dogs were lean and insulin-sensitive. $C t_{\text {target }}=$ average $C t$ for target gene and $C t_{\mathrm{GAPDH}}=$ average $C t$ for $\mathrm{GAPDH}^{17}$. The level of expression in the lean, insulin-sensitive state was arbitrarily set at $100 \%$.

\section{Statistical analysis}

Data are means with their standard errors. Changes and correlations were analysed statistically using non-parametric tests (Statview; Abacus Concepts Inc., Berkeley, CA, USA): Spearman test for correlations, Wilcoxon paired tests for adipose tissue and plasma parameter comparisons between the normal and obese state, and a Welch modified twosample $t$ test for skeletal muscle tissue values. $P<0.05$ was considered significant.

\section{Results}

\section{Weight gain and insulin sensitivity}

Obese steady state was reached when BW was approximately $140 \%$ of initial BW (from 11.1 (SEM 0.8) to 16.1 (SEM 1.6) $\mathrm{kg}$ ). The period of BW gain was 55 (SEM 2) weeks, the rate of BW gain $0.66 \%$ per week, and mean energy intake 1.38 (SEM 0.08) times the National Research Council recommendation for maintenance, based on initial BW.

The plasma glucose and insulin responses of the dogs during the euglycaemic hyperinsulinaemic clamps are shown in Table 3. Basal glucose concentrations were similar and stable in the dogs in both normal and obese states. Similarly, basal insulin concentrations did not differ between obese and normal states. In contrast, postprandial insulinaemia was significantly increased in obese dogs. During the clamp, insulin infusion elevated the plasma insulin value to a steady-state plateau, which averaged $154 \mu \mathrm{U} / \mathrm{ml}$ during the last $2 \mathrm{~h}$. The glucose infusion rate required to maintain euglycaemia under these hyperinsulinaemic conditions was lower in obese dogs than when in their normal state $(P<0.05)$. Overall, body insulin sensitivity was therefore decreased (by approximately $30 \%$ ) by obesity.

\section{Increase in TAG and leptin concentrations, and decrease in adiponectin}

Plasma TAG concentrations $(P<0.05$ compared with normal state) and plasma leptin concentrations $(P<0.05$ compared with normal state) were significantly increased in obese dogs, whilst plasma adiponectin concentrations were significantly decreased in obese animals $(P<0.05$ compared with normal state).

$m R N A$ expression of peroxisome proliferator-activated receptor- $\gamma$, lipoprotein lipase, leptin, GLUT4, TNF $\alpha$ and adiponectin in visceral adipose tissue

The mRNA expression of PPAR $\gamma$ and its target genes in visceral adipose tissue, which was obtained in all seven dogs in both the obese and normal states, is shown in Fig. 1. In visceral adipose tissue, LPL, GLUT4, PPAR $\gamma$ and adiponectin mRNA expression was approximately 2-fold less in the dogs when obese and insulin-resistant, compared with their lean and insulin-sensitive state. In contrast, mRNA expression of

Table 3. Body weight, plasma concentrations of TAG, leptin, adiponectin, postprandial insulinaemia and parameters of hyperinsulinaemic euglycaemic clamp in dogs before and after weight gain leading to obesity $(n 7)$

(Mean values with their standard errors)

\begin{tabular}{|c|c|c|c|c|}
\hline & \multicolumn{2}{|c|}{ Lean state } & \multicolumn{2}{|c|}{ Obese state } \\
\hline & Mean & SEM & Mean & SEM \\
\hline Body weight $(\mathrm{kg})$ & $11 \cdot 1$ & 0.8 & $16 \cdot 1^{*}$ & 1.6 \\
\hline TAG $(\mathrm{mmol} / \mathrm{l})$ & 0.42 & 0.04 & $0.77^{*}$ & 0.06 \\
\hline Leptin (ng/ml) & $7 \cdot 30$ & 2.48 & $56 \cdot 06^{\star}$ & $10 \cdot 39$ \\
\hline Adiponectin (ng/ml) & 94 & 12 & $52^{\star}$ & 6 \\
\hline $\begin{array}{l}\text { Postprandial } \\
\text { insulinaemia }(\mu \mathrm{U} / \mathrm{ml})\end{array}$ & 24 & 4 & $45^{\star}$ & 5 \\
\hline Basal insulinaemia $(\mu \mathrm{U} / \mathrm{ml})$ & 19 & 4 & 24 & 1 \\
\hline Basal glycaemia (g/l) & 0.86 & 0.03 & 0.85 & 0.05 \\
\hline $\begin{array}{l}\text { Plateau of insulin } \\
\text { level }(\mu \mathrm{U} / \mathrm{ml})\end{array}$ & 128 & 4 & 180 & 5 \\
\hline $\begin{array}{l}\text { Glucose infusion } \\
\text { rate }(\mathrm{mg} / \mathrm{kg} \text { per } \mathrm{min})\end{array}$ & $20 \cdot 6$ & 0.3 & $14 \cdot 6^{*}$ & 0.3 \\
\hline
\end{tabular}

Mean values were significantly different from those of the lean state: ${ }^{\star} P<0.05$. 
(A)

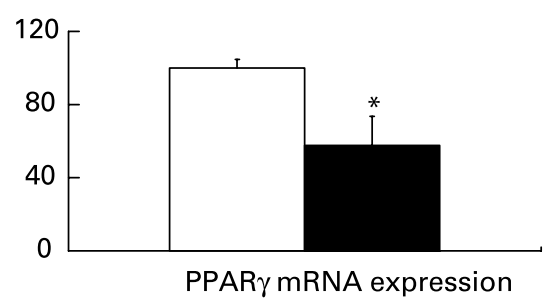

(C)

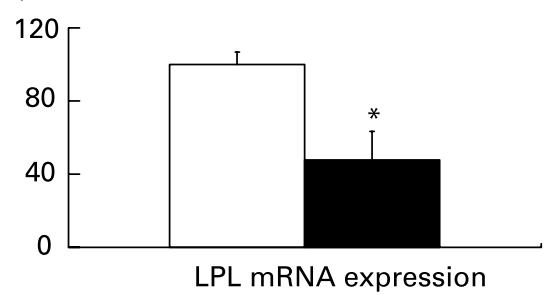

(E)

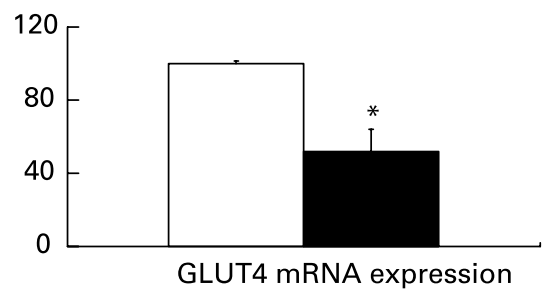

(B)

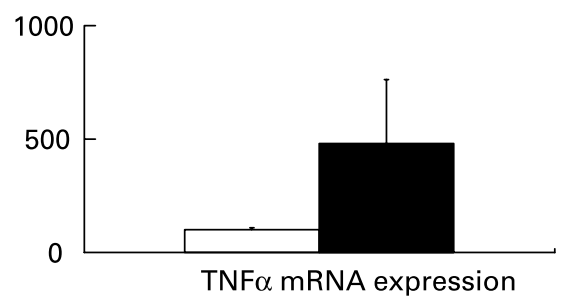

(D)

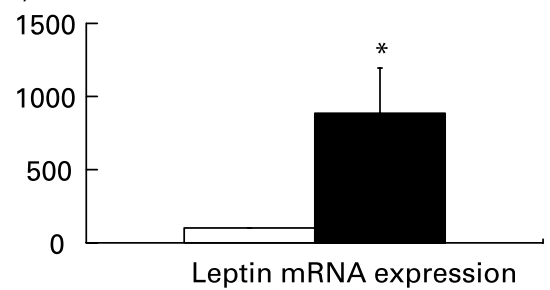

(F)

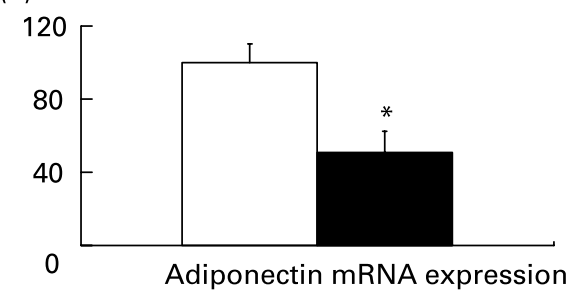

Fig. 1. Relative peroxisome proliferator-activated receptor- $\gamma$ (PPAR $\gamma ; A)$, TNF $\alpha$ (B), lipoprotein lipase (LPL; C), leptin (D), GLUT4 (E) and adiponectin (F) mRNA expression in visceral adipose tissue in obese/insulin-resistant dogs ( $\square$ ) as compared with their lean/insulin-sensitive state ( $\square$; $n$ 7). The level of expression in the lean state was arbitrarily set at $100 \%$. Values are means with their standard errors depicted by vertical bars. Mean values were significantly different from those of the lean state: ${ }^{*} P<0.05$.

leptin in visceral adipose tissue was more than 8-fold higher in the dogs when obese and insulin-resistant, compared with their lean and insulin-sensitive state. mRNA expression of $\mathrm{TNF} \alpha$ was increased by obesity, but this failed to reach significance (481 (SEM 280) and 100 (SEM 9) \%).

mRNA expression of peroxisome proliferator-activated receptor- $\gamma$ in subcutaneous adipose tissue

The mRNA expression of PPAR $\gamma$ in subcutaneous adipose tissue (seven obese dogs, compared with six different lean control dogs) is shown in Fig. 2. Obesity decreased PPARy mRNA in subcutaneous adipose tissue, but this failed to reach significance (38 (SEM 13) and 100 (SEM 36) \%).

mRNA expression of peroxisome proliferator-activated receptor- $\gamma$, lipoprotein lipase and GLUT4 in skeletal muscle

The mRNA expression of LPL, PPAR $\gamma$ and GLUT4 in skeletal muscle, which was obtained from four dogs in both the obese and lean states, is shown in Fig. 3. In skeletal muscle, LPL mRNA expression was approximately 3-fold less in the dogs when obese and insulin-resistant, compared with their lean and insulin-sensitive state. PPAR $\gamma$ and GLUT4 mRNA expression was at least 2-fold less in the dogs when obese and insulin-resistant, compared with their lean and insulinresistant state.
Correlations between mRNA expression of peroxisome proliferator-activated receptor- $\gamma$ and lipoprotein lipase, adiponectin, GLUT4 and leptin in visceral adipose tissue in obese and insulin-resistant dogs

In visceral adipose tissue, there was a positive correlation between PPAR $\gamma$ and leptin mRNA expression $(r$ 0.830, $P<0.05)$, and between PPAR $\gamma$ and adiponectin mRNA expression $(r 0.839$, $P<0 \cdot 05)$. There was no significant correlation between PPAR $\gamma$ and GLUT4 or LPL mRNA expression.

\section{Discussion}

PPAR $\gamma$ increases insulin sensitivity and the utilization of glucose in peripheral tissue by increasing the expression of GLUT4 in target cells ${ }^{18}$. PPAR $\gamma$ also stimulates the storage and uptake of lipids, by increasing the expression of LPL and regulating the expression of cytokines such as leptin and adiponectin.

Several studies have shown that insulin can stimulate ${ }^{19}$ or inhibit $^{20}$ PPAR $\gamma$ expression. Alterations in the expression of PPAR $\gamma$ might participate in the molecular mechanism of diseases with altered lipid homeostasis and insulin resistance, but the relationship between obesity and possible alterations in the expression of PPAR $\gamma$ has not been clearly established.

In the present study, obesity was induced with a high-fat diet. In practice, in both man and domestic animals, obesity is more frequently caused by excessive consumption of a 


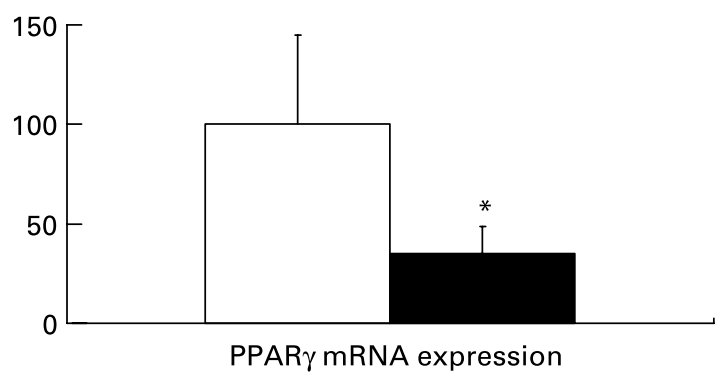

Fig. 2. Relative peroxisome proliferator-activated receptor- $\gamma$ (PPAR $\gamma$ ) mRNA expression in the subcutaneous adipose tissue of obese/insulin-resistant dogs $(\square ; n 7)$ compared with lean, insulin-sensitive control dogs $(\square ; n 6)$. The level of expression in the control group was arbitrarily set at $100 \%$. Values are means with their standard errors depicted by vertical bars. Mean value was not significantly different from that of the control group.

high-carbohydrate diet. Previously described dog models of insulin resistance have used hyper-energetic diets rich in carbohydrate (fructose ${ }^{21}$ ) or $\mathrm{fat}^{22}$, or a normocaloric diet slightly enriched in fat $^{23}$. Numerous studies have shown that excess adiposity is clearly the most important nutrition-related factor determining insulin resistance ${ }^{24}$.

The present data show that obesity induced a decrease in insulin sensitivity (30\%), hyper-triglyceridaemia, hyperleptinaemia, a decrease in plasma adiponectin level and changes in the mRNA expression of PPAR $\gamma$, GLUT4, LPL, adiponectin and leptin in skeletal muscle and/or visceral adipose tissue. It was shown in previous studies that insulin resistance and changes in PPAR $\gamma$ mRNA expression can be related to ageing. However, in the present study, three dogs were fed with a regular control diet for the same period as our experimental dogs. No changes were observed in insulin sensitivity or any plasma parameters (data not shown). Furthermore, the dogs were all young. In agreement with the literature ${ }^{25}$, the present data suggest that the modifications observed in our obese and insulin-resistant dogs were related to obesity and were not due to ageing. The insulin sensitivity of the obese dogs in the present study was significantly decreased, and we found, as has been reported in other species ${ }^{26}$, a decrease in GLUT4 mRNA expression in both insulin target tissues (visceral adipose tissue and skeletal muscle). In parallel, we observed a decrease in PPAR $\gamma$ mRNA expression in the visceral adipose tissue of obese and insulin-resistant animals. Previous findings in mice $^{27}$ and $\operatorname{man}^{28}$ showed also a negative correlation between BMI and PPAR $\gamma$ mRNA expression. However, no change in basal PPAR $\gamma$ mRNA levels in the subcutaneous adipose tissue of obese and type 2 diabetic patients has been reported $^{10}$. Such differences could be due to variability in the stage and characteristics of insulin resistance. The obese dogs in the present study were in a steady state, with stable BW and insulin resistance, but without fasted hyperinsulinaemia and hyperglycaemia.

There is also likely to be variability depending on the source of the tissue studied. It is well-established that increased visceral adiposity is typically seen in people with insulin-resistance syndrome or type 2 diabetes, and that it plays a more prominent pathogenic role than subcutaneous adiposity $^{29,30}$. Indeed, in the subcutaneous adipose tissue of the dogs in the present study, we did not observe any significant modulation of PPAR $\gamma$ expression. In skeletal muscle, we
(A)

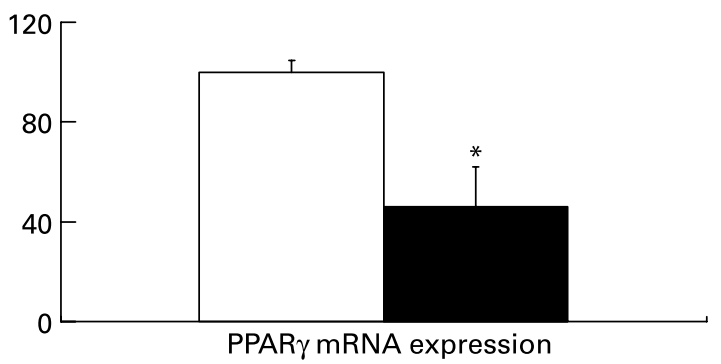

(B)

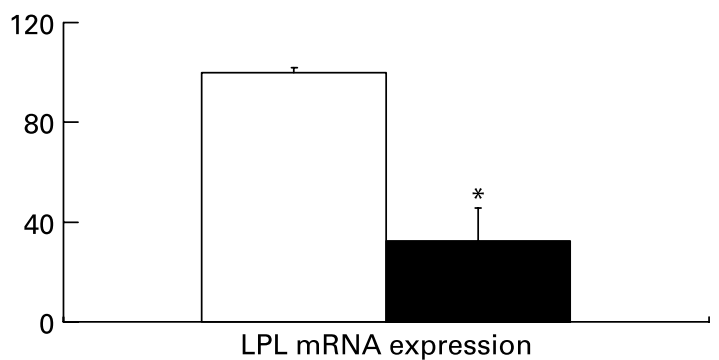

(C)

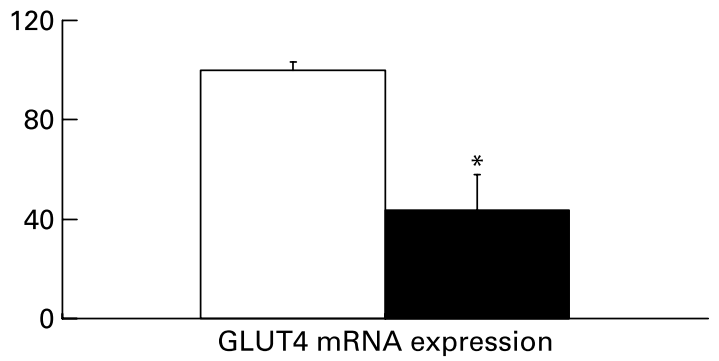

Fig. 3. Relative peroxisome proliferator-activated receptor- $\gamma$ (PPAR $\gamma ; A)$, lipoprotein lipase (LPL; B) and GLUT4 (C) mRNA expression in the skeletal muscle of obese/insulin-resistant dogs (四) as compared with their lean/insulin-sensitive state $(\square ; n 4)$. The level of expression in the lean state was arbitrarily set at $100 \%$. Values are means with their standard errors depicted by vertical bars. Mean values were significantly different from those of the lean state: ${ }^{\star} P<0.05$.

found a decrease in PPAR $\gamma$ mRNA expression. This is in agreement with the fact that mice with a muscle-specific deletion of PPAR $\gamma$ developed excess adiposity as well as whole-body insulin resistance ${ }^{31}$. It has been concluded that PPAR $\gamma$ in muscle could play a role in the regulation of whole-body lipid storage, via alterations in the regulation of genes involved in muscle lipid metabolism. These findings are consistent with our present results. Moreover, the present data support the finding that in vivo activation of PPAR $\gamma$ by treatment of insulin-resistant rodents with thiazolidinediones corrects impaired muscle insulin action ${ }^{32}$.

Our obese dogs exhibited hyper-triglyceridaemia, and in both visceral adipose tissue and skeletal muscle we observed a 2-fold decrease in the mRNA expression of LPL, a major enzyme for TAG hydrolysis that regulates plasma TAG concentration $^{33}$. This suggests insulin resistance-induced abnormalities in LPL function, and is in agreement with data previously reported from our laboratory ${ }^{34}$. In the literature, the reported changes in LPL expression precipitated by 
insulin resistance are contradictory ${ }^{27,35}$. The decreased LPL mRNA expression in skeletal muscle and adipose tissue in the present study is consistent with data reported in man ${ }^{36}$ and mice ${ }^{27}$. Furthermore, it has been showed that LPL mRNA levels decreased following $\mathrm{TNF} \alpha$ perfusion via a transient decrease in PPAR $\gamma$ expression in white adipose tissue $^{37}$.

The increased TNF $\alpha$ mRNA expression in the obese and insulin-resistant dogs in the present study was not significant. This could be due to a high standard deviation caused by the great variability in the degree of obesity achieved by the dogs. Furthermore, in a previous study carried out in our laboratory, we found a significant increase in plasma $\mathrm{TNF} \alpha$ levels in obese and insulin-resistant dogs compared with lean $\operatorname{dogs}^{38}$.

PPAR $\gamma$ is likely to modulate the expression of many other genes, especially the adipocytokines, leptin and adiponectin. In the present study, the hyper-leptinaemia observed in obese and insulin-resistant dogs was associated with a considerable increase in leptin mRNA expression: these data are consistent with an increase in fat mass and with the inhibitory effect of activated-PPAR $\gamma$ on leptin gene expression ${ }^{39,40}$, which could result in the over-expression of the cytokine when PPAR $\gamma$ mRNA expression is altered. The plasma level of adiponectin and its mRNA expression in visceral adipose tissue were significantly decreased in obese and insulin-resistant dogs. The present findings support those obtained in $\operatorname{man}^{5}$ and in rodent models of obesity ${ }^{41}$ where PPAR $\gamma$ has been shown to be a potential regulator of adiponectin ${ }^{6}$. The present therefore suggest that in dogs too, alteration in plasma adiponectin may be due to decreased adiponectin expression following the reduction in PPAR $\gamma$ expression.

In the present study, the mRNA expression of PPAR $\gamma$ in the visceral adipose tissue of obese and insulin-resistant dogs was correlated with the mRNA expression of adiponectin, and leptin, strengthening the hypothesis that an alteration in PPAR $\gamma$ mRNA expression may have a role in insulin resistance. In human skeletal muscle, a positive correlation between expression of PPAR $\gamma$ and LPL mRNA has been described ${ }^{42}$. In canine skeletal muscle we did not find any correlation between PPARy mRNA expression and any of its target genes: the observed changes in mRNA levels were significant, and we used a highly sensitive and reproducible real-time PCR assay, however, the sample size for analyses on this tissue was small (four dogs).

We used a dog model of steady-state obesity (compared with the initial lean state) following a long-term overfeeding period to study the effects of obesity-associated insulin resistance on the mRNA expression of PPAR $\gamma$ and its target genes. Previous studies have shown a similar but shorter-term model of the insulin-resistant dog to be useful for studying human insulin resistance-associated dyslipidaemia ${ }^{34}$. In addition to the changes in lipoprotein metabolism described previously, we observed several other canine parameters that are modulated in the same way as during human insulin-resistance disease. The dogs in the present study developed hyper-triglyceridaemia, suggesting alterations in LPL functionality. Indeed, in insulin-resistant animals, mRNA LPL was decreased in both adipose tissue and skeletal muscle, whilst plasma and mRNA expression of adipocyte-derived cytokines was increased (leptin) and decreased (adiponectin). The mRNA expression of the insulin-dependent glucose transporter GLUT4 was also reduced in skeletal muscle and visceral adipose tissue. We observed consistent changes in mRNA PPAR $\gamma$ expression and furthermore, there was a correlation between mRNA expression of PPAR $\gamma$ and adiponectin and leptin in adipose tissue. In the present study, the expression of PPAR $\gamma$ and its target genes was studied in two insulin target tissues: skeletal muscle (the major site for insulin-stimulated glucose uptake) and visceral adipose tissue (the major adipose compartment associated with insulin resistance). In contrast, most of the data in the literature were obtained solely on subcutaneous adipose tissue.

In summary, all the present findings suggest that, in dogs, obesity-associated insulin resistance alters PPAR $\gamma$ mRNA expression and PPAR $\gamma$-responsive genes that influence metabolism. Considering the notion that insulin resistance is associated with a decrease in PPAR $\gamma$ mRNA expression, in addition to a decrease in its activity, may allow new approaches to the study of this metabolic disorder to be formulated.

\section{Acknowledgements}

We thank Samuel Ninet and Gérald Pondevie for taking care of our animals. We also thank Philippe Bleis for technical support during the biopsies.

\section{References}

1. Okuno A, Tamemoto H, Tobe K, et al. (1998) Troglitazone increases the number of small adipocytes without the change of white adipose tissue mass in obese Zucker rats. J Clin Invest 101, 1354-1361.

2. Schoonjans K, Peinado-Onsurbe J, Lefebvre AM, Heyman RA, Briggs M, Deeb S, Staels B \& Auwerx J (1996) PPARalpha and PPARgamma activators direct a distinct tissue-specific transcriptional response via a PPRE in the lipoprotein lipase gene. EMBO J 15, 5336-5348.

3. Cohen B, Novick D \& Rubinstein M (1996) Modulation of insulin activities by leptin. Science 274, 1185-1188.

4. Miles PD, Romeo OM, Higo K, Cohen A, Rafaat K \& Olefsky JM (1997) TNF-alpha-induced insulin resistance in vivo and its prevention by troglitazone. Diabetes 46, 1678-1683.

5. Maeda N, Takahashi M, Funahashi T, et al. (2001) PPARgamma ligands increase expression and plasma concentrations of adiponectin, an adipose-derived protein. Diabetes 50, 2094-2099.

6. Yamauchi T, Kamon J, Waki H, et al. (2001) The fat-derived hormone adiponectin reverses insulin resistance associated with both lipoatrophy and obesity. Nat Med 7, 941-946.

7. Dana SL, Hoener PA, Bilakovics JM, Crombie DL, Ogilvie KM, Kauffman RF, Mukherjee R \& Paterniti JR Jr (2001) Peroxisome proliferator-activated receptor subtype-specific regulation of hepatic and peripheral gene expression in the Zucker diabetic fatty rat. Metabolism 50, 963-971.

8. Wu Z, Xie Y, Morrison RF, Bucher NL \& Farmer SR (1998) PPARgamma induces the insulin-dependent glucose transporter GLUT4 in the absence of C/EBPalpha during the conversion of 3T3 fibroblasts into adipocytes. J Clin Invest 101, 22-32.

9. Park KS, Ciaraldi TP, Abrams-Carter L, Mudaliar S, Nikoulina SE \& Henry RR (1997) PPAR-gamma gene expression is elevated in skeletal muscle of obese and type II diabetic subjects. Diabetes 46, 1230-1234.

10. Rieusset J, Andreelli F, Auboeuf D, Roques M, Vallier P, Riou JP, Auwerx J, Laville M \& Vidal H (1999) Insulin acutely 
regulates the expression of the peroxisome proliferator-activated receptor-gamma in human adipocytes. Diabetes 48, 699-705.

11. Vidal-Puig AJ, Considine RV, Jimenez-Linan M, Werman A, Pories WJ, Caro JF \& Flier JS (1997) Peroxisome proliferator-activated receptor gene expression in human tissues. Effects of obesity, weight loss, and regulation by insulin and glucocorticoids. J Clin Invest 99, 2416-2422.

12. Barroso I, Gurnell M, Crowley VE, et al. (1999) Dominant negative mutations in human PPARgamma associated with severe insulin resistance, diabetes mellitus and hypertension. Nature 402, 880-883.

13. Bergman RN, Van Citters GW, Mittelman SD, Dea MK, Hamilton-Wessler M, Kim SP \& Ellmerer M (2001) Central role of the adipocyte in the metabolic syndrome. J Investig Med 49, 119-126.

14. Kirkness EF, Bafna V, Halpern AL, et al. (2003) The dog genome: survey sequencing and comparative analysis. Science 301, 1898-1903.

15. Bailhache E, Ouguerram K, Gayet C, Krempf M, Siliart B, Magot T \& Nguyen P (2003) An insulin-resistant hypertriglyceridaemic normotensive obese dog model: assessment of insulin resistance by the euglycaemic hyperinsulinaemic clamp in combination with the stable isotope technique. J Anim Physiol Anim Nutr 87, 86-95.

16. Iwase M, Kimura K, Komagome R, Sasaki N, Ishioka K, Honjoh T \& Saito M (2000) Sandwich enzyme-linked immunosorbent assay of canine leptin. J Vet Med Sci 62, 207-209.

17. Livak KJ \& Schmittgen TD (2001) Analysis of relative gene expression data using real-time quantitative PCR and the $2^{-\Delta \Delta C_{\mathrm{T}}}$ method. Methods 25, 402-408.

18. Young PW, Cawthorne MA, Coyle PJ, Holder JC, Holman GD, Kozka IJ, Kirkham DM, Lister CA \& Smith SA (1995) Repeat treatment of obese mice with BRL 49653, a new potent insulin sensitozer, enhances insulin action in white adipocytes. Association with increased insulin binding and cell-surface GLUT4 as measured by photoaffinity labelling. Diabetes 44, 1087-1092.

19. Zhang B, Berger J, Zhou G, Elbrecht A, Biswas S, White-Carrington S, Szalkowski D \& Moller DE (1996) Insulin- and mitogen-activated protein kinase-mediated phosphorylation and activation of peroxisome proliferator-activated receptor gamma. J Biol Chem 271, 31771-31774.

20. Hu E, Kim JB, Sarraf P \& Spiegelman BM (1996) Inhibition of adipogenesis through MAP kinase-mediated phosphorylation of PPARgamma. Science 274, 2100-2103.

21. Pamies-Andreu E, Fiksen-Olsen M, Rizza RA \& Romero JC (1995) High-fructose feeding elicits insulin resistance without hypertension in normal mongrel dogs. Am J Hypertens 8, 732-738.

22. Rocchini AP, Marker P \& Cervenka T (1997) Time course of insulin resistance associated with feeding dogs a high-fat diet. Am J Physiol 272 (1 Pt 1), E147-E154.

23. Kim SP, Ellmerer M, Van Citters GW \& Bergman RN (2003) Primacy of hepatic insulin resistance in the development of the metabolic syndrome induced by an isocaloric moderate-fat diet in the dog. Diabetes 52, 2453-2460.

24. McAuley K \& Mann J (2006) Thematic review series: patientoriented research. Nutritional determinants of insulin resistance. J Lipid Res 47, 1668-1676.

25. Peterson KF, Befroy D, Dufour S, Dziura J, Ariayan C, Rothman DL, DiPietro L, Cline GW \& Shulman GI (2003) Mitochondrial dysfunction in the elderly: possible role in insulin resistance. Science 300, 1140-1142.

26. Mingrone G, Rosa G, Di Rocco P, Manco M, Capristo E, Castagneto M, Vettor R, Gasbarrini G \& Greco AV (2002) Skeletal muscle triglycerides lowering is associated with net improvement of insulin sensitivity, TNF-alpha reduction and GLUT4 expression enhancement. Int $J$ Obes Relat Metab Disord 26, 1165-1172.

27. Kageyama H, Hirano $T$, Okada K, Ebara T, Kageyama A, Murakami T, Shioda S \& Adachi M (2003) Lipoprotein lipase mRNA in white adipose tissue but not in skeletal muscle is increased by pioglitazone through PPAR-gamma. Biochem Biophys Res Commun 305, 22-27.

28. Montague CT, Prins JB, Sanders L, Zhang J, Sewter CP, Digby J, Byrne CD \& O'Rahilly S (1998) Depot-related gene expression in human subcutaneous and omental adipocytes. Diabetes 47, 1384-1391.

29. Fujioka S, Matsuzawa Y, Tokunaga K \& Tarui S (1987) Contribution of intra-abdominal fat accumulation to the impairment of glucose and lipid metabolism in human obesity. Metabolism 36, 54-59.

30. Kelley DE, Thaete FL, Troost F, Huwe T \& Goodpaster BH (2000) Subdivisions of subcutaneous abdominal adipose tissue and insulin resistance. Am J Physiol 278, E941-E948.

31. Norris AW, Chen L, Fisher SJ, et al. (2003) Muscle-specific PPARgamma-deficient mice develop increased adiposity and insulin resistance but respond to thiazolidinediones. J Clin Invest 112, 608-618.

32. Zierath JR, Ryder JW, Doebber T, et al. (1998) Role of skeletal muscle in thiazolidinedione insulin sensitizer (PPARgamma agonist) action. Endocrinology 139, 5034-5041.

33. Eckel RH (1989) Lipoprotein lipase. A multifunctional enzyme relevant to common metabolic diseases. $N$ Engl J Med 320, 1060-1068. [Erratum in: N Engl J Med (1990) 322, 477.]

34. Bailhache E, Nguyen P, Krempf M, Siliart B, Magot T \& Ouguerram K (2003) Lipoproteins abnormalities in obese insulin-resistant dogs. Metabolism 52, 559-564.

35. Preiss-Landl K, Zimmermann R, Hammerle G \& Zechner R (2001) Lipoprotein lipase: the regulation of tissue specific expression and its role in lipid and energy metabolism. Curr Opin Lipidol 13, 471-481.

36. Boucher P, Ducluzeau PH, Davelu P, Andreelli F, Vallier P, Riou JP, Laville M \& Vidal H (2002) Expression and regulation by insulin of low-density lipoprotein receptor-related protein mRNA in human skeletal muscle. Biochim Biophys Acta 1588, 226-231.

37. Hill MR, Young MD, McCurdy CM \& Gimble JM (1997) Decreased expression of murine PPARgamma in adipose tissue during endotoxemia. Endocrinology 138, 3073-3076.

38. Gayet C, Bailhache E, Dumon H, Martin L, Siliart B \& Nguyen $P$ (2004) Insulin resistance and changes in plasma concentration of TNFalpha, IGF1, and NEFA in dogs during weight gain and obesity. J Anim Physiol Anim Nutr 88, 157-165.

39. De Vos P, Lefebvre AM, Miller SG, Guerre-Millo M, Wong K, Saladin R, Hamann LG, Staels B, Briggs MR \& Auwerx J (1996) Thiazolidinediones repress ob gene expression in rodents via activation of peroxisome proliferator-activated receptor gamma. J Clin Invest 98, 1004-1009.

40. Kallen CB \& Lazar MA (1996) Antidiabetic thiazolidinediones inhibit leptin (ob) gene expression in 3T3-L1 adipocytes. Proc Natl Acad Sci USA 93, 5793-5796.

41. Arita Y, Kihara S, Ouchi N, et al. (1999) Paradoxical decrease of an adipose-specific protein, adiponectin, in obesity. Biochem Biophys Res Commun 257, 79-83.

42. Lapsys NM, Kriketos AD, Lim-Fraser M, Poynten AM, Lowy A, Furler SM, Chisholm DJ \& Cooney GJ (2000) Expression of genes involved in lipid metabolism correlate with peroxisome proliferator-activated receptor gamma expression in human skeletal muscle. J Clin Endocrinol Metab 85, $4293-4297$. 